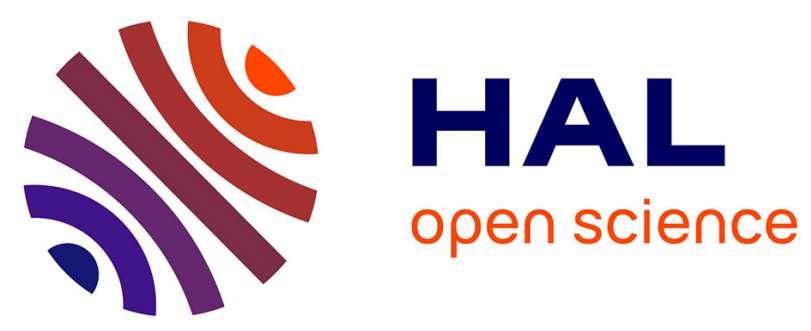

\title{
Diversity of trophic niches among herbivorous fishes on a Caribbean reef (Guadeloupe, Lesser Antilles), evidenced by stable isotope and gut content analyses
}

Charlotte R. Dromard, Yolande Bouchon, Mireille Harmelin-Vivien, Claude

Bouchon

\section{To cite this version:}

Charlotte R. Dromard, Yolande Bouchon, Mireille Harmelin-Vivien, Claude Bouchon. Diversity of trophic niches among herbivorous fishes on a Caribbean reef (Guadeloupe, Lesser Antilles), evidenced by stable isotope and gut content analyses. Journal of Sea Research (JSR), 2015, 95, pp.124 - 131. 10.1016/j.seares.2014.07.014 . hal-01659840

\section{HAL Id: hal-01659840 \\ https://hal.univ-antilles.fr/hal-01659840}

Submitted on 8 Dec 2017

HAL is a multi-disciplinary open access archive for the deposit and dissemination of scientific research documents, whether they are published or not. The documents may come from teaching and research institutions in France or abroad, or from public or private research centers.
L'archive ouverte pluridisciplinaire HAL, est destinée au dépôt et à la diffusion de documents scientifiques de niveau recherche, publiés ou non, émanant des établissements d'enseignement et de recherche français ou étrangers, des laboratoires publics ou privés. 
Diversity of trophic niches among herbivorous fishes on a Caribbean reef (Guadeloupe, Lesser Antilles), evidenced by stable isotope and gut content analyses

Charlotte R. Dromard, ${ }^{\mathrm{a},}$, Yolande Bouchon-Navaro ${ }^{\mathrm{a}}$, Mireille Harmelin-Vivien ${ }^{\mathrm{b}}$, Claude Bouchon $^{\mathrm{a}}$

${ }^{a}$ BOREA - DYNECAR, LABEX CORAIL, Laboratoire de Biologie Marine, Université des Antilles et de la Guyane, Campus de Fouillole, BP 592, 97159 Pointe-à-Pitre, Guadeloupe, FRANCE

${ }^{b}$ Institut Méditerranéen d'Océanologie (MIO), CNRS/INSU, UM 110, Aix-Marseille Université, 13288 Marseille Cedex 9, FRANCE

* Corresponding author. Tel.: +590 590483005; fax: +590 590483283. E-mail address: cdromard@univ-ag.fr (C. Dromard). 


\section{ABSTRACT}

While herbivorous fishes have been widely studied due to the major ecological role they play on coral reefs, the description of their trophic niche remains challenging. In this study, we asked how 10 species of parrotfishes and surgeonfishes partition trophic resources on a Caribbean reef. The determination of trophic niches was conducted using gut and stomach content and stable isotopes analyses $\left({ }^{15} \mathrm{~N}:{ }^{14} \mathrm{~N}\right.$ and ${ }^{13} \mathrm{C}:{ }^{12} \mathrm{C}$ ratios). The contributions of food source to fish diet were calculated with concentration-dependent mixing models. Stomach content analyses distinguished two species of Acanthuridae from other fish species: Acanthurus coeruleus due to its high ingestion of fleshy macroalgae and $A$. chirurgus due to its high ingestion of calcified macroalgae. Acanthuridae and Sparisoma aurofrenatum presented similar diets in terms of assimilation of food resources with a high contribution of detritus and invertebrates to their diets. The diets of Sparisoma rubripinne and $S$. chrysopterum were more heterogeneous by comparison to the previous species. Scarus iseri, S. vetula, $S$. taeniopterus and Sparisoma viride appeared to share a similar trophic niche characterized by the contribution of live coral and fleshy macroalgae to their diet. The resource use among herbivorous fishes was partially related to the nutritional quality of food sources, but also to their physical structure and the capacity of fish to process them efficiently. These results showed that the ten species occupy distinct trophic niches, indicating a high functional diversity among the Caribbean herbivorous fishes.

KEY WORDS: Caribbean reefs, Herbivorous fishes, Trophic niches, Functional diversity, Stable isotopes, Gut contents. 


\section{Introduction}

On coral reefs, parrotfishes (Scaridae) and surgeonfishes (Acanthuridae) represent two common and abundant families of herbivorous fishes that play a major ecological role with regard to the dynamics of benthic communities (Bellwood and Choat 1990, Mumby et al. 2006). High grazing rates control the development of macroalgae and facilitate the recruitment and growth of corals by preventing competition with macroalgae (Carpenter 1986, Lewis 1986, Steneck 1988, Kuffner et al. 2006). Since the decline in 1983 of the sea urchin Diadema antillarum Philippi 1845 (Lessios et al. 1984) and the degradation of corals, which has led to the "coral-algal phase shift" (Hughes 1994, Miller and Hay 1998, McManus and Polsenberg 2004, Bruno et al. 2009), herbivorous fishes have been considered as key species, mediating the balance between corals and algae.

The ecology of herbivorous fishes, including feeding preferences, has been studied before in the Caribbean (Bruggemann et al. 1994, 1996, McAfee and Morgan 1996, Ferreira and Gonçalves 2006, Burkepile and Hay 2008, Cardoso et al. 2009). Following these studies, herbivorous fishes have been divided into functional groups: grazers, scrapers, browsers and bioeroders, based on adult morphology and feeding behavior (Bellwood and Choat 1990, Cardoso et al. 2009, Green and Bellwood 2009). However, the determination of their trophic niche with precision remains challenging.

The trophic niche of a species has been described as the "bionomic" axis of the ecological niche while the "scenopoetic" axis refers to environmental components of the niche (Hutchinson 1978). Trophic niches have been described with digestive content analyses (Randall 1967, Tilghman et al. 2001, Ferreira and Gonçalves 2006) or direct observations of feeding behavior in the field by the counting of "bites" (Frydl and Stearn 1978, McAfee and Morgan 1996, Burkepile and Hay 2008, Cardoso et al. 2009, Kopp et al. 2010). However, these methods do not provide an accurate description of the diet and 
present several practical problems (Bearhop et al. 2004). The principal difficulty comes from the ability of herbivorous fishes to triturate and grind the ingested matter into small fragments, due to the adaptation of their digestive anatomy (gizzard-like stomach for surgeonfishes or pharyngeal mill for parrotfishes) (Randall 1967, Bellwood and Choat 1990).

More recently, stable isotope analyses have been proposed to reflect the feeding behavior of individuals over approximately three months, that corresponds to the period during which the muscles of consumers are synthesized (Maruyama et al. 2001, McIntyre and Flecker 2006). Thus, it has been argued that niche axes (bionomic and scenopoetic axes) may be determined using stable isotope ratios (Bearhop et al. 2004) and have been formalized in the concept of the "isotopic niche" (Newsome et al. 2007) on the basis of the isotopic ratios measured in consumer tissues $\left({ }^{15} \mathrm{~N}:{ }^{14} \mathrm{~N}\right.$ and $\left.{ }^{13} \mathrm{C}:{ }^{12} \mathrm{C}\right)$, which increase in a stepwise fashion with each trophic level and are linked to those of their diet. Generally, constant enrichments between the signatures of consumer and food sources are considered to be $+3.4 \%$ for nitrogen and $+1 \%$ o for carbon (Minagawa and Wada 1984). Some authors demonstrated variations in the $\delta^{15} \mathrm{~N}$ fractionation value for herbivorous fishes: $+4-5 \%$ for Mill et al. (2007), +1.7\%o for Wyatt et al. (2010), +2.5\%o for Vander Zanden and Rasmussen (2001). Recently, Plass-Johnson et al. (2013) recommended a mean nitrogen enrichment equal to $+2.3 \%$ o for parrotfishes, due to their diet consisting of both low and high-proteins foods. The use of stable isotope analyses has considerably increased over the last decades to discriminate different trophic groups in food web studies (Cocheret de la Morinière et al. 2003, Carassou et al. 2008; Wyatt et al. 2012), compare trophic niches in a fish community (Ho et al. 2007, Frédérich et al 2009, Nagelkerken et al. 2009, Layman and Allgeier 2012, Lamb et al. 2012), show ontogenetic changes in diet (Cocheret de la Morinière et al. 2003, Kolasinski et al. 2009, Carreón- 
Palau et al. 2013, Plass-Johnson et al. 2013) or plasticity of feeding habits (Ho et al. 2009). Coupling digestive content and stable isotopes analyses represents a powerful tool to determine trophic niches. A few studies have used these two approaches among the Scaridae and Acanthuridae families (Carassou et al. 2008, Greenwood et al. 2010, PlassJohnson et al. 2013), especially in the Caribbean (Cocheret de la Morinière et al. 2003).

On the basis of isotopic signatures, the use of mixing models has been introduced in ecological studies to estimate the contribution of food sources to the diet of consumers (see Layman et al. 2011 for review). These models use mass balance equations and the distinct isotopic signatures of various sources to determine their relative contribution to the mixed signature of a consumer (Phillips and Koch 2002). As elemental concentrations varied substantially among sources, the mixing model used in the present study incorporated concentration dependence as recommended by Phillips and Koch (2002). This model considers unequal assimilation of carbon and nitrogen and assumes that, for each element, the contribution of a source is proportional to the assimilated biomass times the elemental concentrations in that source. Mixing models can give important information on the feeding habits of fishes, especially when gut content analyses failed to identify some ingested food items. However, since several parameters entered in models can vary, results of mixing models must be interpreted with caution. Firstly, samplings have to be done in a limited temporal and spatial scale due to natural variations in isotopic signatures (Kuerten et al. 2014). Secondly, specific fractionation factors are often unknown and the choice of the constant enrichments requires a carefully review of the literature. Thirdly, a complete collection of the potential food sources present on the study site has to be sampled and integrated in the model to be accurate. In a complex ecosystem like coral reefs, food sources are abundant and some sources can be missing. For these reasons, the use of mixing models to evaluate the contribution of food sources 
in the diet of fish remains rare for coral reefs ecosystems (Wyatt et al. 2012; Letourneur et al. 2013, Plass-Johnson et al. 2013; Kuerten et al. 2014).

At the same time, the quality of food resources could explain their use by fishes (Montgomery and Gerking 1980; Dromard et al. 2013). The nutritional quality of food sources can be evaluated by measuring the concentrations of proteins, lipids and carbohydrates in sources. It is accepted that sources presenting high concentrations of proteins, soluble carbohydrates and lipids are considered as reservoirs of energy, whereas sources constituted by a large amount of insoluble carbohydrates are considered as poorly energizing and difficult to digest (Montgomery and Gerking 1980, Krogdahl et al. 2005). In this study, we coupled gut and stomach content with stable isotopes analyses to describe and compare the trophic niche of ten Caribbean herbivorous fishes. Firstly, these results were used to cluster fish species based on the description of their trophic niche. Secondly, additional data on the nutritional quality of sources were used to understand food choices.

\section{Materials and methods}

\subsection{Field sampling}

The present study was carried out in Guadeloupe, Lesser Antilles $\left(16^{\circ} 00^{\prime} \mathrm{N} ; 61^{\circ} 30^{\prime} \mathrm{W}\right)$. The study site consisted in a outer reef slope located on the leeward side of the island (Fig. 1). A coral community dominated by Orbicella annularis colonized the bottom of the studied site. Sampling was done between September and November 2010, corresponding to the three last months of the 6-months wet season. The study site was limited to a 250 m-radius circle to minimize spatial variations of the isotopic signatures. Ten individuals of the most abundant species of herbivorous fishes were speared and immediately placed in an icebox (Table 1; EMS 1). The most abundant species of mature 
erect macroalgae, called "macroalgae" in this study, were hand collected (Acanthophora spicifera, Dictyota cf pulchella, Tricleocarpa fragilis and Amphiroa fragilissima). Macroalgae were preserved in a plastic bag in order to retain the detritus deposits of the algal thalli. In addition, five replicates of algal turf, defined as a multispecific assemblage of upright branches of primarily filamentous taxa (Hay 1981, Carpenter 1986), were scraped and collected with an air sucker connected to a $500 \mu \mathrm{m}$ mesh collector bag. Larger macroalgae at a juvenile stage, also present in algal turf, were removed from turf samples. In the same way, benthic invertebrates were sorted from turf samples to preserve them as a different potential food source. Finally, five pieces of the live coral Orbicella annularis were sampled and kept on ice.

\subsection{Digestive content analysis}

The total length of fish $\left(L_{\mathrm{T}}\right)$ was measured to the nearest centimeter (Table 1, EMS 1). All the individuals speared had reached their intermediate or terminal phase. Diets were determined by the method of point-intercept, originally described by Jones (1968) and slightly modified in this study. Stomach contents (for surgeonfishes) and gut contents (for parrotfishes), were spread in Petri dishes and placed under a stereomicroscope. Ten different zones on each Petri dish were randomly chosen and photographed (10x magnification). A grid, totalizing 100 intersections, was superimposed on the digitized photographs and the nature of food items observed under each point-intercept was recorded. With this method, 1,000 points were observed for each individual, that is 10,000 per fish species. The results were expressed as percentages of the different categories of food sources that were ingested by fish. To complete information on the diet of the 10 fish species, the principal food items and the suggested functional group cited in the literature is reported in table 1. 


\subsection{Stable isotope analyses}

A small piece of the white dorsal muscle of fishes was sampled for isotope analyses, since white muscles tend to be less variable in terms of isotopic ratios than other tissues (Pinnegar and Polunin 1999) and because turnover of muscles is approximately three months (McIntyre and Flecker 2006, Maruyama et al. 2001) that is less than the period of the wet season (6 months). Due to the small amount collected, benthic invertebrates (principally gastropods) were pooled by sample of turf in which they were collected and whole animals were used for analyses. The thalli of macroalgae and samples of algal turf were cleaned with distilled water to collect deposits (called "detritus" in this study), principally constituted by detrital organic matter and bacteria (Crossman et al. 2001). Corals were scratched with a stainless steel blade to extrude polyps from the calcareous skeleton. All samples collected were cut into small pieces and oven dried at $50^{\circ} \mathrm{C}$ to a constant weight, and then ground into a homogenous fine powder. Carbon and nitrogen stable isotope ratios of fish muscles and sources were performed on two subsamples for food sources that might contain carbonates: calcified macroalgae, algal turf, detritus, invertebrates and corals. For $\delta^{13} \mathrm{C}$, a subsample was acidified, drop-by-drop, with $1 \mathrm{~N} \mathrm{HCl}$ in order to remove calcified material that presents a less negative $\delta^{13} \mathrm{C}$ than organic material (De Niro and Epstein 1978). For $\delta^{15} \mathrm{~N}$, a non-acidified subsample was used, because acidification can distort $\delta^{15} \mathrm{~N}$ values (Pinnegar and Polunin 1999). Nitrogen and carbon isotope ratios were determined by a continuous flow mass spectrometer (Thermo Fisher ${ }^{\mathrm{TM}}$, delta $\mathrm{V}$ Advantage). Elemental concentrations of carbon and nitrogen ([C]\% and $[\mathrm{N}] \%$ ) were measured with an elementary analyzer (Thermo Fisher ${ }^{\mathrm{TM}}$, Flash EA 1112). Isotopic ratios were expressed in standard delta notation [ $\delta$ values (\%o)] according to the following formula: $\delta=\left[\left(R_{\text {sample }} / R_{\text {standard }}-1\right)\right] \times 1000$, where $R$ is the ratio of heavy 
to light isotope $\left({ }^{15} \mathrm{~N}:{ }^{14} \mathrm{~N}\right.$ or $\left.{ }^{13} \mathrm{C}:{ }^{12} \mathrm{C}\right), R_{\text {sample }}$ is measured for fish and sources and $R_{\text {standard }}$ is an international standard (Vienna Pee Dee belemnite limestone carbonate for carbon and atmospheric air for nitrogen).

The Bayesian mixing model SIAR v4.0 (Stable Isotope Analysis in R) developed by Parnell et al. (2010) was used to estimate the proportional contribution of food sources to the diet of fish species. As recommended by Phillips and Koch (2002), the mixing model incorporated concentration dependence. Ten models were run according to each fish species. In each model, we entered the mean carbon and nitrogen signatures $( \pm \mathrm{SD})$ of potential food sources, the mean signatures of fish muscles and the mean elemental concentrations $( \pm \mathrm{SD})$ of the sources $([\mathrm{C}] \%$ and $[\mathrm{N}] \%)$. All food sources collected were used in each model, with the exception of the coral Orbicella annularis that was not included in the models of the Acanthuridae because they are not able to consume coral and coral has never been described as a potential food source for surgeonfishes. . Finally, mixing models considered carbon and nitrogen fractionation factors $\left(\Delta^{13} \mathrm{C}\right.$ and $\left.\Delta^{15} \mathrm{~N}\right)$. Following Plass-Johnson et al. (2013), we adopted a mean enrichment ( \pm SD) of $2.3 \pm$ $0.5 \%$ for the nitrogen because parrotfishes and surgeonfishes have a diet consisting of both high- and low-protein foods. A mean enrichment $( \pm \mathrm{SD})$ of $1.5 \pm 0.5 \%$ o was used for carbon, according to the data given in the literature concerning marine fishes (Sweeting et al. 2007).

\subsection{Nutritional quality of food sources}

Concentrations of proteins, lipids, soluble and insoluble carbohydrates were measured in the potential food sources. Concentrations of proteins were measured according to a modified version of the method of Lowry et al. (1951). This procedure is well adapted to the analysis of marine algae, while the quantification of proteins may differ according to 
methods (Barbarino and Lourenço 2005). Soluble and insoluble carbohydrates were determined by a modified version of the method of Dubois et al. (1956). Finally, lipids were extracted and measured following the method of Bligh and Dyer (1959), modified by Mayzaud and Martin (1975). All concentrations were expressed as a percentage of organic matter analyzed.

\subsection{Statistical analysis}

Data were tested for normality with the Shapiro-Wilks test and for homogeneity of variance with Levene's test. The proportions of food items found in the digestive contents, isotopic signatures and concentrations of macronutrients were compared using multivariate analyses of variance (MANOVA). When significant difference were found with MANOVAs, Tukey's honestly significant difference (HSD) post hoc tests were used to perform multiple comparisons. The mean contributions of food sources to fish diet, calculated with mixing models, were compared between fish species with a Chi-square test. All statistical analyses were performed using the program $\mathrm{R}$.

\section{Results}

\subsection{Gut and stomach content analyses}

Four categories of food were identified in the digestive contents: calcified macroalgae, fleshy macroalgae, algal turf and benthic invertebrates (Fig. 2). A large amount of unidentified material was observed in digestive contents but was not regarded as a source because of its uncertain origin (detritus or highly digested material). A review of the diet and the suggested functional group cited in the literature are reported in Table 1. In the present study, the mean proportion of fleshy macroalgae ingested by Acanthurus coeruleus was significantly higher than for the other species (mean $\pm \mathrm{CI}=30.2 \pm 7.5 \%$; 
Tukey, all $\mathrm{p}<0.001)$. A. coeruleus was the only species to ingest benthic invertebrates (principally gastropods), even if their mean proportion was low (mean $\pm \mathrm{CI}=6.0 \pm$ 3.2\%). Acanthurus chirurgus differed from the other fish in showing higher proportions of calcified macroalgae in its stomach content $(15.0 \pm 2.8 \%$; Tukey, $\mathrm{p}<0.001)$.

Differences in the proportions of food items ingested by Scaridae were difficult to show because a large amount of unidentified organic matter was found in its gut contents (Fig. 2).

\subsection{Isotopic niches of fishes}

Stable isotopes values $\left(\delta^{15} \mathrm{~N}\right.$ and $\delta^{13} \mathrm{C}$ ) are presented as a bi-plot (Fig. 3). Among the food sources, carbon and nitrogen signatures of food sources were significantly different from each other (MANOVA, Wilks' lambda $=0.004, \mathrm{~F}_{9,36}=60.8, \mathrm{p}<0.0001$ ). However, multiple comparisons showed that Dictyota cf pulchella and Acanthophora spicifera presented similar isotopic signatures of carbon and nitrogen (Tukey, both $\mathrm{p}>0.99$ ). Carbon and nitrogen signatures of fish muscles were also significantly different between fish species (MANOVA, Wilks' lambda $=0.10, \mathrm{~F}_{9,60}=10.6, \mathrm{p}<0.0001$ ). The three species of Acanthuridae exhibited the highest isotopic signatures of nitrogen that ranged from $5.6 \pm 0.2 \%$ for Acanthurus bahianus to $6.9 \pm 0.9 \%$ for $A$. coeruleus. The isotopic signatures of Scaridae were scattered, especially for the carbon signature that ranges from $-15.3 \pm 0.4 \%$ for Sparisoma aurofrenatum to $-12.0 \pm 0.3 \%$ for Scarus vetula.

The positions of fish and food resources in the bi-plot suggested different feeding habits (Fig. 2). Scarus taeniopterus, S. iseri, S. vetula and Sparisoma viride presented the lowest nitrogen signatures and the highest carbon signature, showing a trend to consume more fleshy macroalgae and more coral than other fish species. Sparisoma aurofrenatum and the three species of Acanthuridae displayed the highest nitrogen signatures and the lowest 
carbon signatures, suggesting a bigger consumption of invertebrates, detritus or algal turf. Isotopic signatures of Sparisoma rubripinne and S. chrysopterum were intermediate, suggesting an intermediate and a more heterogeneous diet than other fish species.

\subsection{Mixing models}

Due to their close isotopic signatures, Dictyota cf pulchella and Acanthophora spicifera were grouped in a single food category, called "fleshy macroalgae" (Table 2). The contributions of food sources to the fish diet were significantly different between fish species (Chi-square test, $X_{2}=293.7$, d.f. $=54, P<0.0001$ ). According to the mean contributions of sources ( $95 \%$ bayesian credibility intervals), different groups of species appeared (Fig. 4, EMS 2). Acanthurus coeruleus, A. chirurgus, A. bahianus and Sparisoma aurofrenatum constituted a first group of fishes, characterized by a high contribution to their diet of detritus, calcified macroalgae (Tricleocarpa fragilis and Amphiroa fragilissima) and benthic invertebrates. Scarus taeniopterus, S. vetula, S. iseri and Sparisoma viride assimilated preferentially fleshy macroalgae combined with coral tissues and formed a second group of fishes (Fig. 4, EMS 2). Sparisoma chrysopterum and S. rubripinne composed a third group, distinguished by smaller contributions of invertebrate and detritus to their diet than species from the first group.

\subsection{Nutritional quality of food sources}

The eight potential sources presented different concentrations of macronutrients (MANOVA, Wilks' lambda $=0.001, \mathrm{~F}_{7,36}=23.7, P<0.0001$ ) and thus, different nutritional qualities. Corals and invertebrates represented the highest nutritional sources due to their high concentrations of proteins, lipids and soluble carbohydrates and low concentrations of insoluble carbohydrates (Table 3). Acanthophora spicifera, Dictyota $\mathrm{cf}$ 
pulchella and detritus presented an intermediate nutritional quality. In contrast, Tricleocarpa fragilis, Amphiroa fragilissima and algal turf were characterized by high concentrations of insoluble carbohydrates, and low concentrations of proteins and lipids. These three sources showed the lowest nutritional quality.

\section{Discussion}

\subsection{Trophic niches of herbivorous fishes}

Isotopic signatures of fish muscles were significantly different according to the fish species, indicating that herbivorous fishes use differentially the food resources present on coral reefs.

Acanthurus coeruleus exhibited the highest nitrogen signatures indicating a higher trophic position. Indeed, stomach content analyses distinguished A. coeruleus from the other species by its higher consumption of fleshy macroalgae, algal turf and invertebrates. Mixing models also indicated a high contribution of benthic invertebrates and detritus. Its specific trophic niche can be explained by its digestive anatomy, especially its thinwalled stomach, which is well adapted to the consumption of soft resources like fleshy macroalgae or detritus (Ogden and Lobel 1978). This result was in accordance with previous studies describing A. coeruleus as the only "browser" among the herbivorous fishes on Caribbean coral reefs (Ferreira and Gonçalves 2006).

The stomach contents of $A$. chirurgus showed the highest proportions of calcified macroalgae, probably made possible by its thick-walled, gizzard-like stomach (Ogden and Lobel 1978) while A. bahianus ingested more algal turf. For the two latter species of Acanthuridae, the results of the mixings models were close. Ferreira and Gonçalves (2006) also demonstrated that $A$. bahianus and A. chirurgus presented more similar diets than A. coeruleus. 
The nitrogen signatures of Scaridae were lower than those of Acanthuridae, indicating a different use of the food sources. The present study showed the limits of gut contents analyses for Scaridae because of the difficulty to identify food items. Indeed, a large amount of unidentified organic matter was found in the digestive contents of Scaridae. However, mixing models displayed differences in the assimilation of food resources for these species. Sparisoma aurofrenatum seemed to have a similar diet than Acanthuridae, in terms of proportions of assimilated food items. These results were in accordance with the previous classification of herbivorous fishes into functional groups, since $S$. aurofrenatum, Acanthurus chirurgus and A. bahianus are defined as "grazers" in the literature (Bellwood and Choat 1990, Cardoso et al. 2009, Green and Bellwood 2009).

S. rubripinne and S. chrysopterum are also classified as "grazer" but their diet differed from those of the previous species by a smaller contribution of invertebrates and detritus. Mixing models also indicated the contribution of coral to the diets of these two species. Few observations of live coral consumption have been recorded for these two species (Cardoso et al. 2009). However, Bruggemann et al. (1996) suggested that S. rubripinne and $S$. chrysopterum could be classified as excavators, leading to a probable consumption of corals.

Scarus taeniopterus, $S$. iseri, $S$. vetula and Sparisoma viride were characterized by the assimilation of the coral Orbicella annularis. These four species, considered as "scrapers" and "bioeroders" for the larger species (Bruggemann et al. 1994, Cardoso et al. 2009), are able to bite into corals because of their stronger jaws. While corals had not been identified as a main item in their diet (Randall 1967), these species have been observed feeding on live corals (Frydl and Stearn 1978, Rotjan and Lewis 2008, Cardoso et al. 2009, Roff et al. 2011). In the present study, the results of mixing models showed that corals could represent important inputs of carbon and nitrogen to the diet of these 
three species. Mixing models also suggested a considerable assimilation of fleshy macroalgae by these species even if small amounts of macroalgae were found in the digestive contents of these species. Macroalgae may have been highly broken by the powerful jaws of Scaridae and quickly digested. That could explain the large part of unidentified organic matter found in gut contents.

Even if the consumption of macroalgae has been described before (Cardoso et al. 2009, Burkepile and Hay 2011), herbivorous fishes are known to avoid mature erect macroalgae, leading to an incapacity for them to reverse a coral-algal phase-shift once it is established (Mumby 2006, Francini-Filho et al. 2010, Kopp et al. 2010). The important contribution of fleshy macroalgae calculated with mixing models, could be linked to the consumption of macroalgae at a juvenile stage present in algal turf, which were excluded from turf during the preparation of samples.

Herbivorous fishes do not occupy the same single trophic niche on the studied reefs. These results indicated a high functional diversity among herbivorous fishes in the Caribbean, even if their specific richness is relatively low compared to other regions of the world (Choat et al. 2002, Bellwood et al. 2003, Bonaldo et al. 2006, Choat et al. 2004).

\subsection{Resource use by herbivorous fishes}

Corals and benthic invertebrates presented the highest nutritional quality. Fish that were able to consume corals (parrotfishes) assimilated this source in large proportions. However, mixing models could have overestimated the contribution of corals to their diet, precisely because of its high nutritional quality (Newsome et al. 2011). Indeed, Newsome et al. (2011) suggested that, for animals fed with moderate to high amounts of protein foods, mixing models can overestimate the contribution of dietary protein sources 
to diet, because the incorporation of dietary protein carbon was dependent on dietary protein content and on each amino acid's biosynthesis pathway. Benthic invertebrates also presented a high nutritional quality. While few were found in gut contents, benthic invertebrates contribute to the diets of several species, especially Acanthuridae. It is possible that invertebrates were ingested by fishes but quickly digested and thus difficult to identify in gut contents. Acanthophora spicifera and Dictyota cf pulchella presented an intermediate nutritional quality. In mixing models, these two macroalgae species were grouped in the same food category ("fleshy macroalgae") because of their similar isotopic signatures. The results showed that herbivorous fishes assimilated fleshy macroalgae in large proportions, but we suggested that $A$. spicifera contributed more to the assimilation of fleshy macroalgae than Dictyota cf pulchella, because A. spicifera has often been described as a highly palatable macroalgae in studies assessing grazing pressure by herbivorous fishes (Lewis 1985, Reinthal and Macintyre 1994). At the same time, the low palatability of Dictyota sp for herbivorous fishes was explained by its high content of deterrent molecules (Vallim et al. 2005, Fong and Paul 2011). The high assimilation of fleshy macroalgae could also be linked to other macroalgae species, because fleshy macroalgae can have very close isotopic signatures at the same site (Dromard et al. 2013). Previous studies demonstrated the important role of detritus in the diet of herbivorous fishes (Crossman et al. 2001, Wilson et al. 2003, Crossman et al. 2005, Ferreira and Gonçalves 2006, Max et al. 2013). In this study, detritus represented an intermediate nutritional quality and was assimilated by fishes, probably because it constitutes tiny easily digestible particles. Algal turf has been described as the major food resource for herbivorous fishes, principally because of the presence of detritus in the mat (Hatcher 1983, Horn 1989, Choat et al. 2002, Wilson et al. 2003). This information was verified here because the turf showed a lower nutritional quality than detritus. In this 
study, fishes that assimilated the highest amount of algal turf (Acanthuridae, Scarus taeniopterus and Sparisoma aurofrenatum) also complemented their diet with the assimilation of fleshy macroalgae, invertebrates or corals and detritus. Calcified macroalgae showed the lowest nutritional quality, with small concentrations of macronutrients, in addition to their calcareous contents. Consequently, herbivorous fishes, especially Scaridae, presented low assimilations of calcified macroalgae. According to Montgomery and Gerking (1980), the ingestion of calcified macroalgae seems to be independent of a nutritional function and could be used to grind other food items. Calcified macroalgae contributed principally to the diet of Acanthuridae, probably because their muscular stomachs enable them to ingest this type of source, in contrast to other herbivores (Scaridae, Pomacentridae, Kyphosidae). Thus, the resources use by herbivorous fishes depends on several factors as the nutritional quality of sources or their physical structure (presence or absence of calcareous contents or carapaces). The use of other food sources is linked to the capacity of some fishes to collect them (such as corals for some parrotfishes).

To our knowledge, this study is the first assessment of resource assimilation by herbivorous fishes in the Caribbean, using an isotopic approach. Mixing models highlighted the contributions of food sources, especially those that were difficult to identify in digestive contents or by direct observations, such as detritus or coral tissue. However, the use of mixing models is widely open to debate (Fry 2013a, Fry 2013b, Semmens et al. 2013) and the results have to be interpreted with caution. First, the fractionation factors used in this study were chosen according to the literature. However, these factors are difficult to evaluate and the use of different factors can slightly influence the results of the mixing models. Different fractionation factors have been suggested for herbivorous fishes (Mill et al. 2007, Wyatt et al. 2010) but no one have been specifically 
identified for Scaridae. Secondly, even if the principal resources were collected at the studied site, coral reefs are complex systems and missing resources could also change the contributions calculated in the present study.

\section{Conclusions}

In the present study, we described different types of trophic niches among Caribbean herbivorous fishes, occupied by one or several species. This diversity could result from a feeding strategy to share the food resources on reefs and to avoid competitive interactions between fish species from similar functional groups. The diversity of trophic niche implies that herbivorous fishes play different ecological roles on reefs, partitioning their food resources. The functional diversity of herbivorous fishes, based on both stable isotope and gut content analyses, was demonstrated in the Indian Ocean (Plass-Johnson et al. 2013) but is highlighted for the first time, to our knowledge, in the Caribbean with the present study. Herbivorous fishes are often overfished in the Caribbean region (Mumby et al. 2006). Due to the importance of their complementary ecological roles on coral reefs, it appears primordial to think about their conservation and to maintain their diversity in the Caribbean.

Acknowledgements

The authors express their thanks to P. Richard and G. Guillou, Université de la Rochelle CNRS UMR LIENSs, for performing stable isotope analyses. We thank S. Cordonnier and L. Urvoix for their help in field sampling and M.F. Fontaine for her help in biochemical analyses. We also thank the three referees for their constructive comments on an earlier draft of the manuscript. 
Dromard et al. Trophic niches of herbivorous fishes 


\section{References}

Barbarino E, Lourenço SO (2005) An evaluation of methods for extraction and quantification of protein from marine macro- and microalgae. J Appl Phycol $17: 447-460$

Bearhop S, Adams CE, Waldrons S, Fuller RA, Macleod H (2004) Determining trophic niche width: a novel approach using stable isotope analysis. J Anim Ecol 73:1007-1012

Bellwood DR, Choat JH (1990) A functional analysis of grazing in parrotfishes (family Scaridae): the ecological implications. Environ Biol Fish 28:189-214

Bellwood DR, Hoey AS, Choat JH (2003) Limited functional redundancy in high diversity systems: resilience and ecosystem function on coral reefs. Ecol Lett 6:281-285

Bligh EG, Dyer WJ (1959) A rapid method of total lipid extraction and purification. Can J Biochem Physiol 37:911-917

Bonaldo RM, Krajewski JP, Sazima C, Sazima I (2006) Foraging activity and resource use by three parrotfish species at Fernando de Noronha Archipelago, tropical West Atlantic. Mar Biol 149:423-433

Bruggemann JH, Kuyper MWM, Breeman AM (1994) Comparative analysis of foraging and habitat use by the sympatric Caribbean parrotfish Scarus vetula and Sparisoma viride (Scaridae). Mar Ecol Prog Ser 112:51-66

Bruggemann JH, van Kessel AM, van Rooij JM, Breeman AM (1996) Bioerosion and sediment ingestion by the Caribbean parrotfish Scarus vetula and Sparisoma viride: implication of fish size, feeding mode and habitat use. Mar Ecol Prog Ser 134:59-71

Bruno JF, Sweatman H, Pretch WF, Selig ER, Schutte GW (2009) Assessing evidence of phase shifts from coral to macroalgal dominance on coral reefs. Ecology 90:1478-1484

Burkepile DE, Hay ME (2008) Herbivore species richness and feeding complementarity affect community structure and function on a coral reef. Proc Natl Acad Sci USA 105:16201-16206

Burkepile DE, Hay ME (2011) Feeding complementarity versus redundancy among herbivorous fishes on a Caribbean reef. Coral Reefs 30:351-362

Carassou L, Kulbicki M, Nicola TJR, Polunin NVC (2008) Assessment of fish trophic status and relationships by stable isotope data in the coral reef lagoon of New Caledonia, southwest Pacific. Aquat Living Resourc 21:1-12

Cardoso SC, Soares MC, Oxenford HA, Côté IM (2009) Interspecific differences in foraging behaviour and functional role of Caribbean parrotfish. Marine Biodiversity Records 2:1-6

Carreón-Palau L, Parrish CC, del Angel-Rodríguez JA, Pérez-España H, Aguiñiga-García S (2013) Revealing organic carbon sources fueling a coral reef food web in the Gulf of Mexico using stable isotopes and fatty acids. Limnol Oceanogr 58: 593-612

Carpenter RC (1986) Partitioning herbivory and its effects on coral reef algal communities. Ecol Monogr 56:345-364

Choat JH, Clements KD, Robbins WD (2002) The trophic status of herbivorous fishes on coral reefs 1. Dietary analyses. Mar Biol 140:613-623

Choat JH, Clements KD, Robbins WD (2004) The trophic status of herbivorous fishes on coral reefs 2. Food proceeding modes and trophodynamics. Mar Biol 


\section{$145: 445-454$}

Cocheret de la Morinière E, Pollux BJA, Nagelkerken I, Hemminga MA, Huiskes AHL, van der Velde G (2003) Ontogenetic dietary changes of coral reef fishes in the mangrove-seagrass-reef continuum: stable isotopes and gut-content analysis. Mar Ecol Prog Ser 246:279-289

Crossman DJ, Choat JH, Clements KD, Hardy T, McConochie J (2001) Detritus as food for grazing fishes on coral reefs. Limnol Oceanogr 46:1596-1605

Crossman DJ, Choat JH, Clements KD (2005) Nutritional ecology of nominally herbivorous fishes on coral reefs. Mar Ecol Prog Ser 296:129-142

De Niro MJ, Epstein S (1978) Influence of diet on the distribution of carbon isotopes in animals. Geochim Cosmochim Acta 42:495-506

Dromard RC, Bouchon-Navaro Y, Cordonnier S, Fontaine MF, Verlaque M, HarmelinVivien M, Bouchon C (2013) resource use of two damselfishes, Stegastes planifrons and Stegastes adustus, on Guadeloupean reefs (Lesser Antilles): inference from stomach content and stable isotope analysis. J Exp Mar Biol Ecol 440:116-125

Dubois M, Gilles K, Hamilton J, Rebers P, Smith F (1956) Colorimetric method for determination of sugars and related substances. Anal Chem 28:350-356

Ferreira CEL, Gonçalves JEA (2006) Community structure and diet of roving herbivorous reef fishes in the Abrolhos Archipelago, south-western Atlantic. J Fish Biol 69:1533-1551

Fong P, Paul VJ (2011) Coral reef algae. In: Dubinsky Z, Stambler N (eds) Coral reefs: an ecosystem in transition. Springer, New York, p 241-272

Francini-Filho RB, Ferreira CM, Coni EO, De Moura RL, Kaufman L (2010) Foraging activity of roving herbivorous reef fish (Acanthuridae and Scaridae) in eastern Brazil: influence of resource availability and interference competition. J Mar Biol Assoc UK 90:481-492

Frédérich B, Fabri G, Lepoint G, Vandewalle P, Parmentier E (2009) Trophic niches of thirteen damselfishes (Pomacentridae) at the Grand Récif of Toliara, Madagascar. Ichthyol Res 56: 10-17

Fry B (2013a) Alternative approaches for solving undetermined isotope mixing models. Mar Ecol Prog Ser 472:1-13

Fry B (2013b) Minmax solutions for underdetermined isotope mixing problems: Reply to Semmens et al. (2013). Mar Ecol Prog Ser 490: 291-294

Frydl P, Stearn CW (1978) Rate of bioerosion by parrotfish in Barbados reef environments. J Sedim Petrol 48:1149-1158

Green AL, Bellwood DR (2009) Monitoring functional groups of herbivorous fishes as indicators of coral reef resilience-A practical guide for coral reef managers in the Asia Pacific region. IUCN working group on climate change and coral reefs. IUCN, Gland, Switzerland

Greenwood NDW, Sweeting CJ, Polunin NVC (2010) Elucidating the trophodynamics of four coral reef fishes of the Solomon Islands using $\delta^{15} \mathrm{~N}$ and $\delta^{13} \mathrm{C}$. Coral Reefs 29:785-792

Hatcher BG (1983) Grazing in coral reef ecosystems. In: Barnes DJ (eds) Perspectives on coral reefs. Australian Institute of Marine Science Contributions 200, Canberra, p 96-179

Hay ME (1981) The functional morphology of turf-forming seaweeds: persistence in stressful marine habitats. Ecology 62:739-750

Ho CT, Kao SJ, Dai CF, H HL, Shiah FK, Jan RQ (2007) Dietary separation between two 
blennies and the Pacific Gregory in northern Taiwan: evidence from stomach content and stable isotope analyses. Mar Biol 151: 729-736

Ho CT, Fu YC, Sun CL, Kao SJ, Jan RQ (2009) Plasticity of feeding habits of two Plectroglyphidodon Damselfishes on coral reefs in southern Taiwan: evidence from stomach content and stable isotope analyses. Zool Stud 48: 649-656

Horn MH (1989) Biology of marine herbivorous fishes. Oceanogr Mar Biol Annu Rev 27:167-272

Hughes TP (1994) Catastrophes, phase shifts, and large-scale degradation of a Caribbean coral reef. Science 265:1547-1551

Hutchinson GE (1978) An introduction to population biology. Yale University Press, New Haven.

Jones RS (1968) A suggested method for quantifying gut contents in herbivorous fishes. Micronesica 2:369-371

Kolasinski J, Frouin P, Sallon A, Rogers K, Bruggemann HJ, Potier M (2009) Feeding ecology and ontogenetic dietary shift of yellowstripe goatfish Mulloidichthys flavolineatus (Mullidae) at Reunion Island, SW Indian Ocean. Mar Ecol Prog Ser 386: $181-195$

Kopp D, Bouchon-Navaro Y, Cordonnier S, Haouisée A, Louis M, Bouchon C (2010) Evaluation of algal regulation by herbivorous fishes on Caribbean coral reefs. Helgol Mar Res 64:181-190

Kuffner IB, Walters LJ, Becerro MA, Paul VJ, Ritson-Williams R, Beach KS (2006) Inhibition of coral recruitment by macroalgae and cyanobacteria. Mar Ecol Prog Ser 323:107-117

Kuerten B, Al-Aidaroos AM, Struck U, Khomayis HS, Gharbawi WY, Sommer U (2014) Influence of environmental gradients on $\mathrm{C}$ and $\mathrm{N}$ stable isotope ratios in coral reef biota of the Red Sea, Saudi Arabia. J Sea Res 85: 379-394

Krogdahl A, Hemre GI, Mommsen TP (2005) Carbohydrates in fish nutrition: digestion and absorption in postlarval stages. Aquac Nutr 11:103-122

Lamb K, Swart PK, Altabet MA (2012) Nitrogen and carbon isotopic systematics of the Florida reef tract. Bull Mar Sci 88:119-146

Layman CA, Araujo MS, Boucek R, Hammerschlag-Peyer CM, Harrison E, Jud ZR, Matich P, Rosenblatt AE, Vaudo JJ, Yeaver LA, Post DM, Bearhop S (2011) Applying stable isotopes to examine food-web structure: an overview of analytic tools. Biol Rev 87: 545-562

Layman CA, Allgeier JE (2012) Characterizing trophic ecology of generalist consumers: a case study of the invasive lionfish in the Bahamas. Mar Ecol Prog Ser 448: $131-141$

Lessios HA, Robertson DR, Cubit JD (1984) Spread of Diadema mass mortality through the Caribbean. Science 226:335-337

Letourneur Y, Lison de Loma T, Richard P, Harmelin-Vivien ML, Cresson P, Banaru D, Fontaine MF, Gref T, Planes S (2013) Identifying carbon sources and trophic position of coral reef fishes using diet and stable isotope $\left(\delta^{15} \mathrm{~N}\right.$ and $\left.\delta^{13} \mathrm{C}\right)$ analyses in two contrasted bays in Moorea, French Polynesia. Coral reefs 32: 1091-1102

Lewis SM (1985) Herbivory on coral reefs: algal susceptibility to herbivorous fishes. Oecologia 65:370-375

Lewis SM (1986) The role of herbivorous fishes in the organization of a Caribbean reef community. Ecol Monogr 56:184-200

Lowry OH, Rosebrough NJ, Farr AL, Randall RJ (1951) Protein measurement with the Folin phenol reagent. J Biol Chem 193:265-275 
Maruyama A, Yamada Y, Rusuwa B, Yuma M (2001) Change in stable isotope ratio in the muscle tissue of a migratory goby, Rhinogobius sp., in a natural setting. Can J Fish Aquat Sci 58: 2125-2128

Mayzaud P, Martin JLM (1975) Some aspect of the biochemical and mineral composition of marine plankton. J Exp Mar Biol Ecol 17:297-310

Max LM, Hamilton SL, Gaines SD, Warner RR (2013) Benthic processes and overlying fish assemblages drive the composition of benthic detritus on a central Pacific coral reef. Mar Ecol Prog Ser 482:181-195

McAfee ST, Morgan SG (1996) Resource use by five sympatric parrotfishes in the San Blas Archipelago, Panama. Mar Biol 125:427-437

McIntyre PB, Flecker AS (2006) Rapid turnover of tissue nitrogen of primary consumers in tropical freshwaters. Oecologia 148: 12-21

McManus JW, Polsenberg JF (2004) Coral-algal phase shifts on coral reefs: ecological and environmental aspects. Prog Oceanogr 60:263-279

Mill AC, Pinnegar JK, Polunin NVC (2007) Explaining isotope trophic step fractionation: why herbivorous fish are different. Funct Ecol 21:1137-1145

Miller MW, Hay ME (1998) Effects of fish predation and seaweed competition on the survival and growth of corals. Oecologia 113:265-238

Minagawa M, Wada E (1984) Stepwise enrichment of ${ }^{15} \mathrm{~N}$ along food chains: further evidence and the relation between $\delta^{15} \mathrm{~N}$ and animal age. Geochim Cosmochim Acta 48:1135-1140

Montgomery WL, Gerking SD (1980) Marine macroalgae as food for fishes: an evaluation of potential food quality. Environ Biol Fish 5:143-153

Mumby PJ (2006) Phase shifts and the stability of macroalgae communities on Caribbean coral reefs. Coral Reefs 28:761-773

Mumby PJ, Dahlgren CP, Harborne AR, Kappel CV, Micheli F, Brumbaugh DR, Holmes KE, Mendes JM, Broad K, Sanchirico JN, Buch K, Box S, Stoffle RW, Gill AB (2006) Fishing, trophic cascades, and the process of grazing on coral reefs. Science 311:98-101

Nagelkerken I, van der Velde G, Wartenbergh SLJ, Nugues NM, Pratchett MS (2009) Cryptic dietary components reduce dietary overlap among sympatric butterflyfishes (Chaetodontidae). J Fish Biol 75: 1123-1143

Newsome SD, Martinez del Rio C, Bearhop S, Phillips DL (2007) A niche for isotopic ecology. Front Ecol Environ 5:429-436

Newsome SD, Fogel ML, Kelly L, Martinez del Rio C (2011) Contributions of direct incorporation from diet and microbial amino acids to protein synthesis in Nile tilapia. Funct Ecol 25:1051-1062

Ogden JC, Lobel PS (1978) The role of herbivorous fishes and urchins in coral reef communities. Environ Biol Fish 3:49-63

Parnell AC, Inger R, Bearhop S, Jackson AL (2010) Source partitioning using stable isotopes: coping with too much variation. PloS ONE 5:e9672

Phillips DL, Koch PL (2002) Incorporating concentration dependence in stable isotope mixing models. Oecologia 130:114-125

Pinnegar JK, Polunin NVC (1999) Differential fractionation of $\delta^{13} \mathrm{C}$ and $\delta^{15} \mathrm{~N}$ among fish tissues: implication for the study of trophic interactions. Funct Ecol 13:225-231

Plass-Johnson JG, McQuaid CD, Hill JM (2013) Stable isotope analysis indicates a lack of inter- and intra-specific dietary redundancy among ecologically important coral reef fishes. Coral Reefs 32:429-440

Randall JE (1967) Food habits of reef fishes of the West Indies. Stud Trop Oceanogr 
5:665-847

Reinthal PN, Macintyre IG (1994) Spatial and temporal variations in grazing pressure by herbivorous fishes: Tobacco Reef, Belize. Atoll Res Bull 425:1-14

Roff G, Ledlie MH, Ortiz JC, Mumby PJ (2011) Spatial patterns of parrotfish corallivory in the Caribbean: the importance of coral taxa, density and size. PLoS ONE 6(12):e29133

Rotjan RD, Lewis SM (2008) Impact of coral predators on tropical reefs. Mar Ecol Prog Ser 367:73-91

Semmens BX, Ward EJ, Parnell AC, Phillips DL, Bearhop S, Inger R, Jackson A, Moore JW (2013) Statistical basis and outputs of stable isotope mixing models: Comments on Fry (2013). Mar Ecol Prog Ser 490: 291-294

Steneck RS (1988) Herbivory on coral reefs: a synthesis. Proc $6^{\text {th }}$ Int Coral Reef Symp $1: 37-49$

Sweeting CJ, Barry JT, Polunin NVC, Jennings S (2007) Effects of body size and environment on diet-tissue $\delta^{13} \mathrm{C}$ fractionation in fishes. $\mathrm{J}$ Exp Mar Biol Ecol 352:165-176

Tilghman GC, Klinger-Bowen R, Francis-Floyd R (2001) Feeding electivity indices in surgeonfish (Acanthuridae) of the Florida Keys. Aquarium Sci Conserv 3:215-223

Vallim MA, Campos De Paula J, Crespo Pereira R, Laneuville Teixeira V (2005) The diterpenes form Dictyotacean marine brown algae in the Tropical Atlantic American region. Biochem Sys Ecol 33: 1-16

Vander Zanden MJ, Rasmussen JB (2001) Variation in $\delta^{15} \mathrm{~N}$ and $\delta^{13} \mathrm{C}$ trophic fractionation: implications for aquatic food web studies. Limnol Oceanogr 46: 2061-2066

Wilson SK, Bellwood DR, Choat JH, Furnas MJ (2003) Detritus in the epilithic algal matrix and its use by coral reef fishes. Oceanogr Mar Biol Annu Rev 41:279-309

Wyatt ASJ, Waite AM, Humphries S (2010) Variability in isotope discrimination factors in coral reef fishes: implications for diet and food web reconstruction. PLoS ONE 5(10):e13682

Wyatt ASJ, Waite AM, Humphries S (2012) Stable isotope analysis reveals communitylevel variation in fish trophodynamics across a fringing coral reef. Coral Reefs 31 : 1029-1044 
Figures

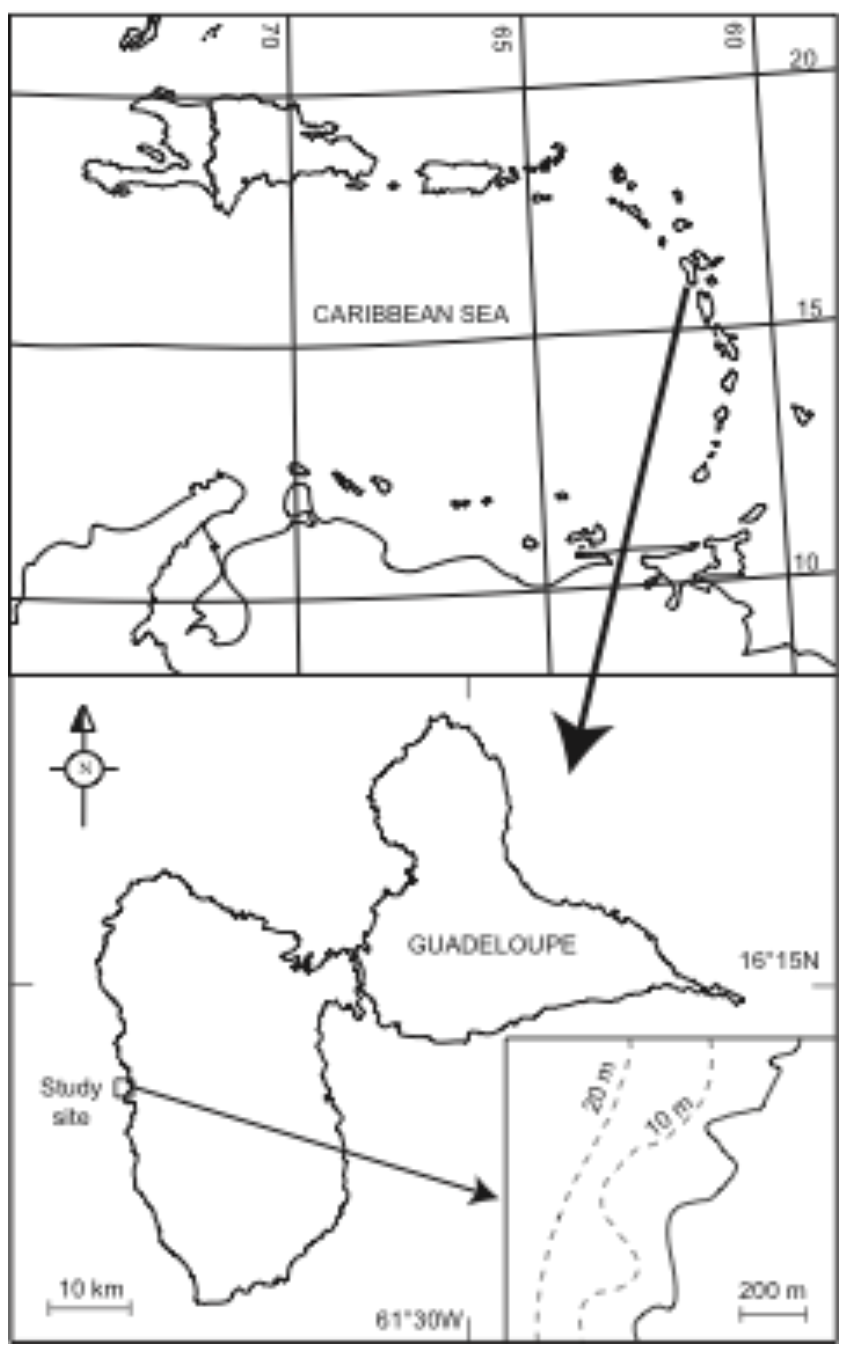

Fig. 1. Location of the study site in Guadeloupe (Lesser Antilles). 


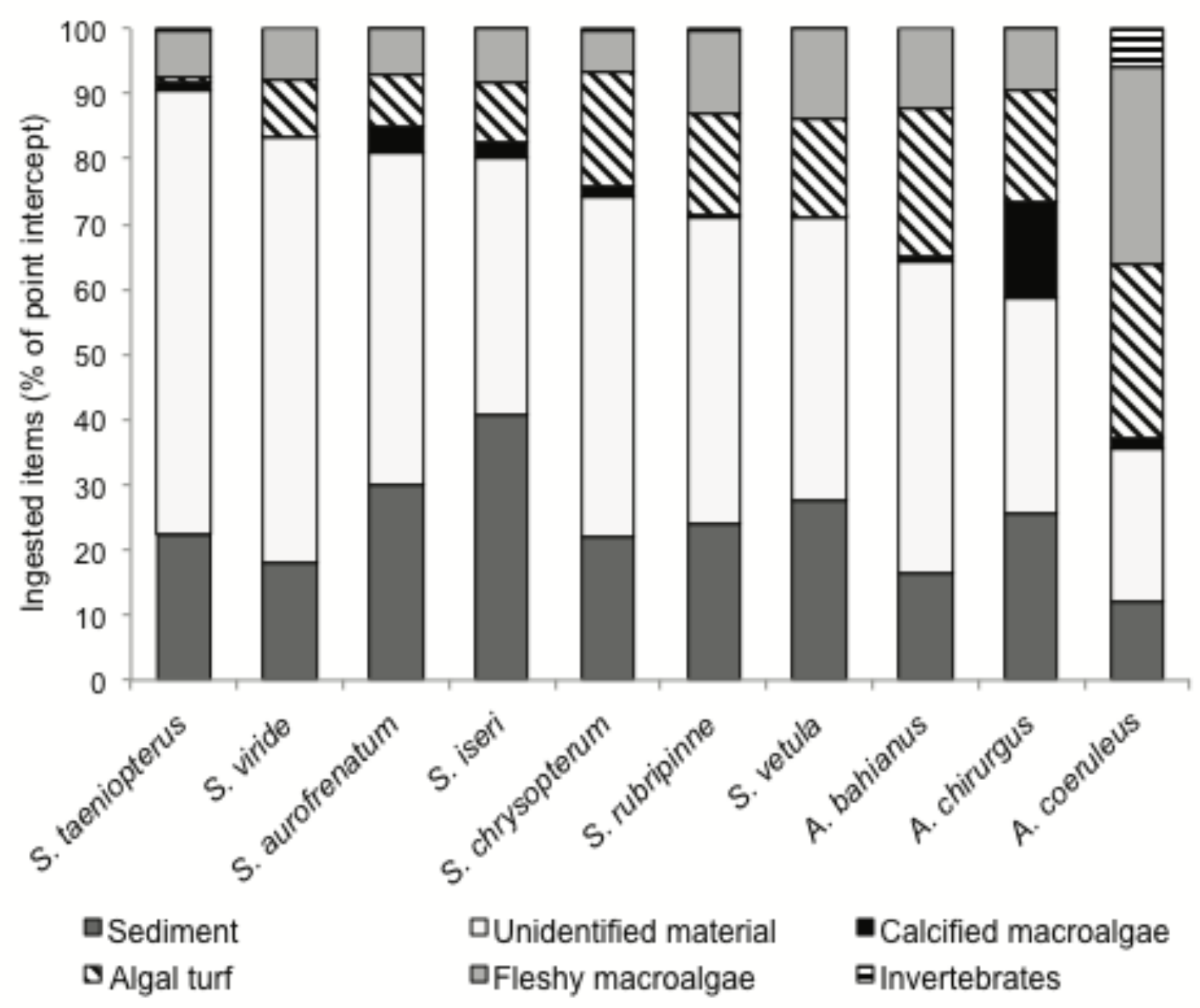

Fig. 2. Proportions of food categories ( $\%$ of point-intercept based on 10,000 observations per fish species) measured in gut and stomach contents of fishes. 


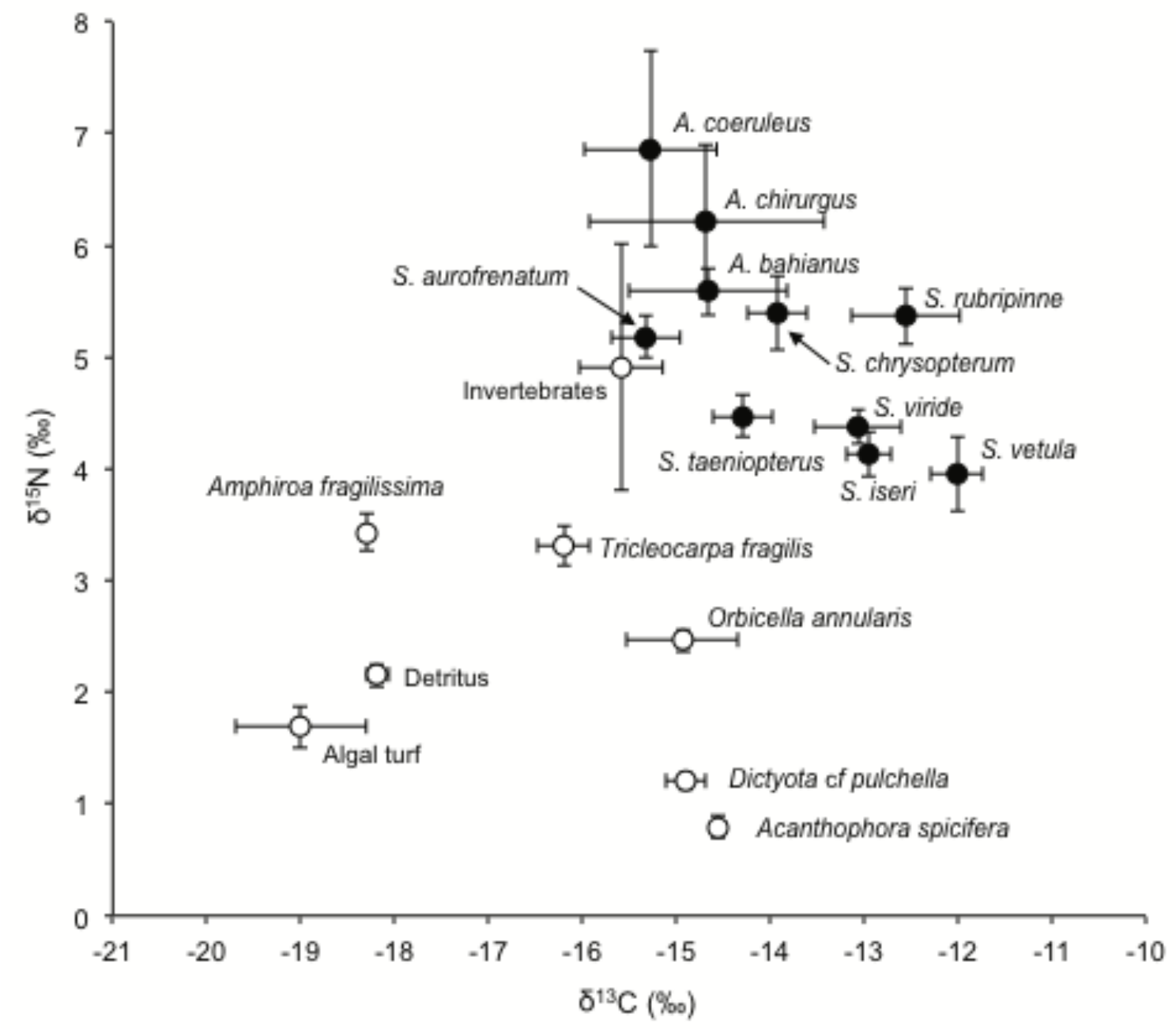

Fig. 3. Mean $( \pm 95 \% \mathrm{CI}) \delta^{13} \mathrm{C}$ and $\delta^{15} \mathrm{~N}$ signatures of fish muscles and the potential food sources (close symbols indicate consumers and open symbols show the potential food sources). 


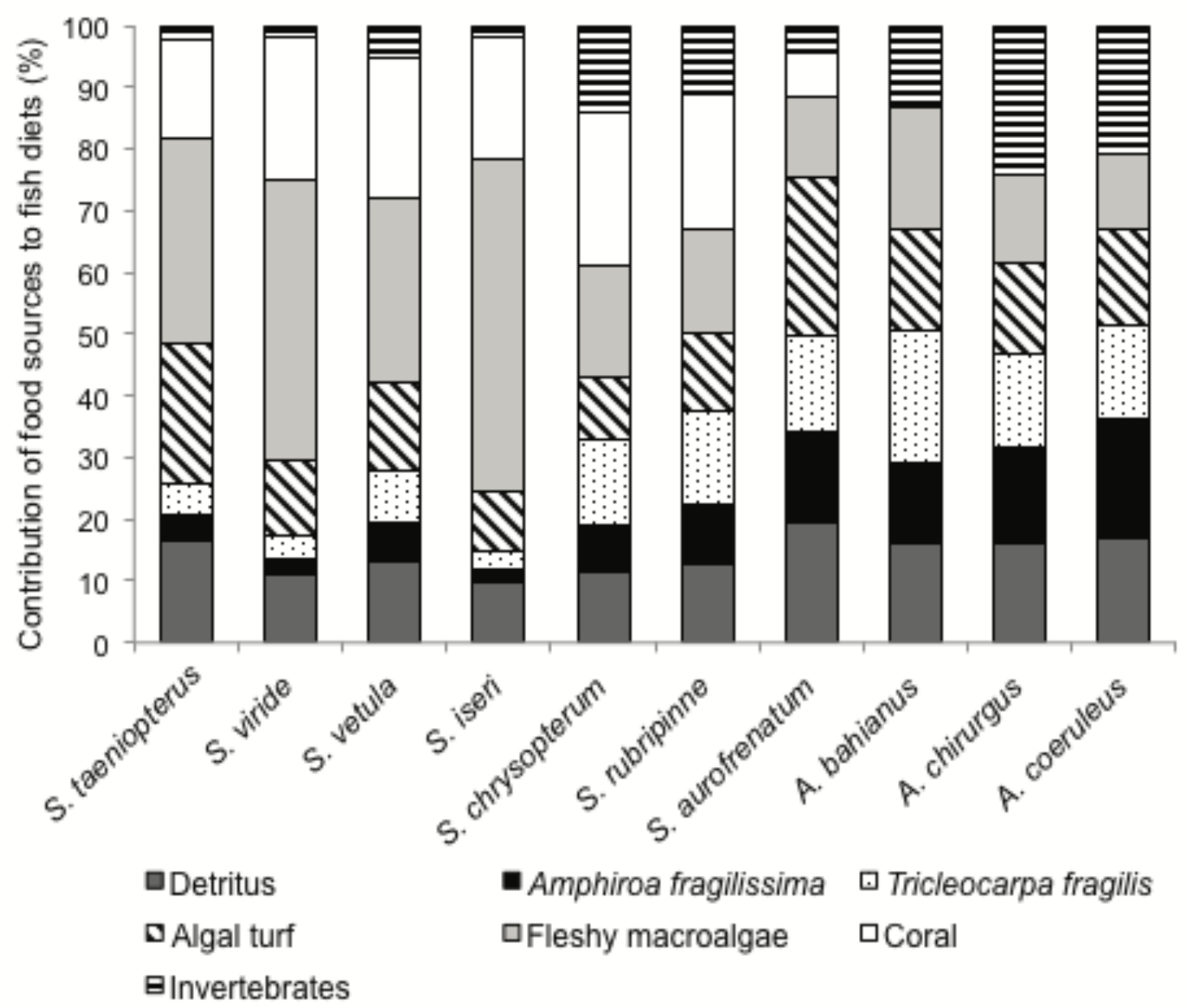

Fig. 4. Mean contribution of food sources to the diet of fish, estimated with mixing models. Fleshy macroalgae: Dictyota cf pulchella and Acanthophora spicifera, Coral : Orbicella annularis. 
Table 1 Mean total length $T_{\mathrm{L}}$ in $\mathrm{cm}$ (range) of the ten studied fish species. Suggested functional groups and principal food items are reported from the literature. " Algae » indicate both macroalgae and epilithic algal turf. Food items into brackets are secondary food sources cited in the literature.

\begin{tabular}{|c|c|c|c|}
\hline Fish species & $T_{\mathrm{L}}(\mathrm{cm})$ & Functional groups ${ }^{\mathrm{b}, \mathrm{c}, \mathrm{e}}$ & Food items \\
\hline Acanthurus bahianus & $17.0(16-19)$ & Grazer & Algae and organic detritus ${ }^{a, c}$ \\
\hline Acanthurus coeruleus & $22.0(16-26)$ & Browser & $\begin{array}{c}\text { Algae }{ }^{c} / \text { Algae and organic } \\
\text { detritus }^{\text {a }}\end{array}$ \\
\hline Acanthurus chirurgus & $19.0(16-23)$ & Grazer & Algae and organic detritus ${ }^{a, c}$ \\
\hline Scarus iseri & $19.0(17-22)$ & Scraper & Algae $^{a} /$ Macroalgae $^{b} /$ Turf $^{d}$ \\
\hline Scarus taeniopterus & $21.0(19-25)$ & Scraper & $\underset{(\text { corals }}{\text { Algae }^{\mathrm{a}, \mathrm{f}} / \mathrm{Macroal}^{\mathrm{b}} / \operatorname{Turf}^{\mathrm{b}} /}$ \\
\hline Scarus vetula & $24.0(19-37)$ & $\begin{array}{l}\text { Scraper/ } \\
\text { Bioeroder }\end{array}$ & $\begin{array}{c}\text { Algae } \\
\left(\text { corals }^{\mathrm{a}, \mathrm{f}}\right)\end{array}$ \\
\hline Sparisoma viride & $26.0(24-30)$ & Bioeroder & $\underset{\left(\text { corals }^{\text {A,f }}\right)}{\text { Algae }}{ }^{\mathrm{a}} /$ Macroalgae $^{\mathrm{b}} / \operatorname{Turf}^{\mathrm{b}} /$ \\
\hline Sparisoma aurofrenatum & $20.3(19-23)$ & Grazer & $\begin{array}{c}\left.\text { Algae }_{\mathrm{b} /\left(\text { corals }^{\mathrm{a}, \mathrm{d}} / \mathrm{f}\right.}\right) \\
\text { Macroalgae }\end{array}$ \\
\hline Sparisoma chrysopterum & $26.0(19-34)$ & Grazer & Algae ${ }^{a} /$ Macroalgae ${ }^{b}$ \\
\hline Sparisoma rubripinne & $20.0(16-30)$ & Grazer & Algae ${ }^{a} /$ Macroalgae ${ }^{b}$ \\
\hline
\end{tabular}

${ }^{\mathrm{a}}$ Randall (1967); ${ }^{\mathrm{b}}$ Cardoso et al. (2009); ${ }^{\mathrm{c}}$ Ferreira and Gonçalves (2006); ${ }^{\mathrm{d}}$ McAfee and Morgan (1996), ${ }^{\mathrm{e}}$ Green and Bellwood (2009); ${ }^{\mathrm{f}}$ Rotjan and Lewis (2008)

Table 2 Mean $\pm \mathrm{CI} \delta^{13} \mathrm{C}(\%)$, $\delta^{15} \mathrm{~N}(\%)$ of food sources and consumers used in mixing models. Mean $\pm \mathrm{CI}$ elemental concentrations $([\mathrm{C}] \%$ and $[\mathrm{N}] \%)$ of sources were also used in mixing models. Fleshy macroalgae: Dictyota cf pulchella and Acanthophora spicifera. $\mathrm{n}$ is the number of samples collected on the reef.

\begin{tabular}{lccccc}
\hline Sample types & $\mathrm{n}$ & $\delta^{13} \mathrm{C}(\% \mathrm{c})$ & $\delta^{15} \mathrm{~N}(\% \mathrm{o})$ & {$[\mathrm{C}] \%$} & {$[\mathrm{~N}] \%$} \\
\hline Detritus & 5 & $-18.2 \pm 0.1$ & $2.2 \pm 0.1$ & $6.8 \pm 0.1$ & $0.8 \pm 0.02$ \\
Algal Turf & 5 & $-19.0 \pm 0.6$ & $1.7 \pm 0.2$ & $7.6 \pm 1.0$ & $2.1 \pm 0.5$ \\
Fleshy macroalgae & 6 & $-14.7 \pm 0.2$ & $1.0 \pm 0.2$ & $12.3 \pm 3.0$ & $1.9 \pm 0.2$ \\
Amphiroa fragilissima & 3 & $-18.3 \pm 0.02$ & $3.4 \pm 0.2$ & $17.4 \pm 5.8$ & $9.2 \pm 0.8$ \\
Tricleocarpa fragilis & 6 & $-16.2 \pm 0.4$ & $3.3 \pm 0.2$ & $24.0 \pm 4.2$ & $8.5 \pm 0.5$ \\
Orbicella annularis & 7 & $-14.9 \pm 0.6$ & $2.5 \pm 0.1$ & $44.8 \pm 2.4$ & $6.7 \pm 1.2$ \\
Benthic invertebrates & 5 & $-15.6 \pm 0.4$ & $4.9 \pm 1.1$ & $44.5 \pm 1.1$ & $7.5 \pm 0.4$ \\
\hline
\end{tabular}

